\title{
Native Authorities and Local Government Reforms in Nigeria Since 1914
}

\author{
Enyi John Egbe, Ph.D \\ Department Of Political Science Benue State University, Makurdi, Nigeria
}

\begin{abstract}
The paper discusses Native Authorities and Local Government Reforms in Nigeria in historical perspectives i.e. from 1914 to the present day. The reform spans from the colonial period, especially from the 1950s to the Military eras, culminating in the present democratic system of Local Government Administration in Nigeria. The paper also discusses the major aims, objectives, achievements and challenges which confronted the six major reform measures between 1914 and 1999. The methodology adopted for the analysis of the work is the extensive review of relevant and extant literature on the subject matter, while the concept of "Reforms" is employed as an explanatory model. The major findings are that each reform measure was necessitated by the short-comings inherent in the preceding system; some of the reforms were far reaching and had positive impacts, while others were cosmetic in nature and mainly for political expediency. It was also found out that some of the Local government reforms, however structured and operated were more like decentralized units of the regional and later state governments. The paper recommends among other things the strengthening of local governments in the country, through deliberate and conscious enactment of relevant laws and policy directives, the retention of the present democratic system of Local Government based on presidentialism, the granting of considerable autonomy, especially financial autonomy to enable the third tier institutions in the country to perform their statutory functions effectively. Finally, the paper concludes that since the local government today remains the key institution in local governance, the basic unit of the country's political system, the primary level of grassroots political mobilization, and a major reference point in the distribution by government of certain economic and social goods and services to the people, constant and meaningless reforms should be avoided so that local governments can take root so as to remain stable and viable grassroots institutions.
\end{abstract}

\section{Introduction}

The system of local government administration practiced anywhere in the world, is dependent largely on the historical, geographical, sociological, political and economic life of the people. This is no less true of Nigeria with a long history of slavery and colonization as well as civilian and military administrations and these have to a large extent determined the system of local government administration in Nigeria up till today. We intend in this work to look at the various reforms that local government system in Nigeria has witnessed since 1914.

The Native Authority (NA) system was the first colonial system of local government administration whereby indirect rule and exploitation was the order of the day. A unified local government system was established in Northern Nigeria before it was extended to Southern Nigeria with varying degrees of success. This system of local government as found in the Native Authorities did not satisfy the needs and aspirations of the local people, hence there were intense agitations from the local citizens, particularly the educated elites in Southern Nigeria craving for greater participation in their own affairs.

The first reform came as a result of the failure of the colonial local government system to meet the needs and aspirations of the people. Thus, after the Second World War in 1945, the colonial policies on local government changed coupled with the demands for greater participation and this led to the adoption of the representative or liberal democratic system of local government in the 1950s. By this time, self-government in Nigeria had been attained and a federal system of government had been entrenched in the Macpherson Constitution of 1951. Thus, each region practiced different systems of local government. The changes in the south were pervasive while a gradualist approach was adopted in the North. The new reforms soon ran into serious problems, particularly in the south due to many factors. However, owing to lack of funds and personnel, coupled with intense politicking no reforms could be initiated until the military seized power in January 1966 which rudely terminated the First Republic.

The third reform started when military leaders assumed power in Nigeria in January 1966 and it lasted from 1966-1975. The reforms were intended to correct the ills of the local government system they inherited. By this time 12 states had been created by the military and the various state governments adopted the system that suited them. It must be stated here that the reforms did not depart markedly from the previous system. The local 
government system ran by the various state governments, however structured and operated were more like decentralized units of the state governments.

The fourth and very important reform came during the administration of General Murtala Muhammed and General Olusegun Obasanjo in 1976. This reform was the most revolutionary in the history of local government reforms in Nigeria. The objectives and functions assigned to the local governments were far reaching. It entrenched a high level of democratic participation and autonomy to the local councils. During the Second Republic, under President Shehu Shagari, the various state governments ran the Local Governments under caretaker arrangements. No Local Government elections were held throughout the period. There was massive proliferation of Local Governments by the states, which were later scrapped because of their unviability by General Mohammadu Buhari when he sized power in 1983. The minor reforms carried out by General Ibrahim Babangida in the 1980s, following the Dasuki and Coker Reports were to correct some of the anomalies associated with the 1976 Reforms. The fundamental basis of the reforms remained essentially that of the 1976 reform.

The fifth reform came in the 1990s during the era of General Ibrahim Babangida who for the first time introduced presidentalism into the local government system in Nigeria. This entailed the abolition of the Ministries of Local Government throughout the country in order to give greater autonomy to the third tier system. This system survived for a while but was suspended when General Sani Abacha assumed power and returned the local governments to parliamentary system.

The sixth and current reform came in the wake of the return to democratic rule in 1999. The 1999 Constitution at Section 7(1) placed the local government councils firmly under the states' control. Therefore, the various state governments have adopted the presidential system of administration in their states. This entails the establishment of two arms at the local level i.e. the executive and the legislative arms with their different functions. This system has been on for the past 13 years, but it would appear that like the previous reforms, the new system is due for a thorough review in view of its many inadequacies.

From all indications, it would appear that the problems with the various reforms have to do more with the operators of the systems and not the system per se. A detailed survey will be undertaken in this work.

\subsection{Conceptual Clarification}

There are three important concepts to be clarified in this paper. There are Native Authority (NA), Local Government and reform.

Native Authority: Native Authority is usually associated with the system of local government administration introduced by the British Colonial Administration to Nigeria in 1914. It was practiced under the famous Indirect Rule System introduced by Sir Fredrick Lord Lugard. According to Lugard (in Kirt Green, 1965:68, Orewa, G.O. and Adewumi, J.B. 1983) Native Authority or Indirect Rule is viewed as:

Rule through Native Chiefs who were regarded as an integral part of the machinery of government with well defined powers and functions recognized by government and by law and not dependent on the caprice of an executive officer.

Also Perham (1973:345) sees the term as "a system by which the tutelary power recognizes existing African societies and assist them to adopt to the functions of local government.

\section{Local Government}

Local government is defined by the United Nations (1959) as a political subdivision of a nation which is constituted by law and has substantial control of local government affairs including the power to impose taxes. The governing body of such an entity is elected or otherwise locally selected. In his own contribution to the definition of local government, Oyediran (1988:8) view the concept as:

Government in which popular participation both in the choice of decision-makers and in the decision-making process is conducted by the local bodies, which while recognizing the supremacy of the central government, is able and willing to accept responsibility for its decisions.

According to the Federal Government Guide-lines for Local Government Reform (1976), local government is:

Government at local level exercise through representative councils established by law to exercise specific powers within defined area. These powers should give the council substantial control over local affairs as well as the staff and institutional and financial services and to determine and implement projects so as to compliment the activities of the state and federal government in their areas and to ensure, through devolution of functions to these councils, the 
active participation of the people and their traditional institutions, that local initiative and response to local needs are maximized.

Also according to Akpan (1984:28) from the above definitions, one can conveniently say that the term 'Local government' is a theoretical abstraction which refers to a sovereignty. Implicit in this statement is the fact that local government bodies are created and derive their powers from the state or central government. inspite of this fact, local government bodies have corporate legal identity (person) and can sue and be sued.

\section{Reform}

On many occasions, leaders undertake reforms in order to achieve effectiveness and efficiency. Olaleye (2001) sees reforms as an attempt to reconstruct administrative structure and revamp operational machinery and techniques capable of improving organizational effectiveness and efficiency. This definition shows that reforms may occur for the purpose of addressing problems arising in operation, structure and organization of an institution.

Administrative reforms therefore refer to purposeful change introduced to improve the capacity of a given organization to respond to changing demands. To Adewumi (1988:20) administrative reforms are usually embarked upon on the assumption that "it is possible and feasible to reach the optimal level in the working of a given organization if the administrative process is fully equipped to provide such support". Administrative reforms should be purposeful or goal oriented changes which are designed to improve the skills as well as the preparedness of members to satisfy the organizational set goals or objectives.

Akaakuma, A. (2008) opines that reform involves identifying an existing problem and attempting to solve it. It has to do with policies formulated and aimed at restructuring and transforming an organization from a bad condition to a better one. This concept will form the theoretical basis of analysis of this work because it best captures the whole essence of the discussion.

\subsection{Native Authority System of Local Government (1914-1959)}

The original system of local government introduced by the British Colonial administration after the amalgamation of the Northern and Southern Protectorates in 1914 was the Native Authority (N.A) system under indirect rule. The legal basis of the N.A was the Native Authority Ordinance of 1916.

Indirect rule was introduced piece meal and in stages until it was practiced in all parts of Nigeria with varying degree of success. The Native Authorities were not democratically elected but were appointive. Those appointed were therefore, not representative of their people but the colonial government.

The authorities were structured to contain four (4) main components viz: the Resident, who was an appointed public officer, was very powerful; the Native Authority normally headed by a Chief; was very powerful; the Native Treasury and the Native Court (Gboyega 1987:14). The authorities so constituted combined Legislative, Executive and Judicial powers. The main functions of the Authorities, however, were to maintain law and order and to collect taxes for colonial government. Very little attention was devoted to the development of the local areas.

The British colonial government introduced the indirect Rule system in Nigeria because it was the most feasible in view of the large size and population of the country. Besides, there was lack of funds and enough staff to cope with the administration of the vast areas. The period of indirect rule was characterized by the exploitation of Nigeria by the British government for their own interests. Harbours, roads, railways, the civil services, and the introduction of cash crops were meant to serve the British colonial interests.

In the North, particularly in the Hausa/Fulani areas, the Native Authority system under the indirect rule found a very congenial environment to thrive. There was a centralized political system over the Muslim North established after the conquest of the Habe Hausa rulers by the Fulani Jehadists led by Usman Dan Fodio. In addition, they had developed a relatively efficient administrative system which enhanced the integration and control of the political system. There was a highly developed judicial system, which applied the Sharia code. There also existed a system of taxation to maintain the Fulani rule over the Hausa. This taxation rested upon the right of conquest and was rigidly exerted. Finally, the Muslim North was hierarchically stratified society and this greatly helped in the administration of the areas.

In the Western part of Nigeria, indirect rule system was partly successful because of the monarchical nature of the existing political system. Prior to colonial rule, the Yorubas lived in Kingdoms with centralized monarchical system under the Obas. There also existed large kingdoms in the Benin and Delta areas. They had a tradition of royal courts to try civil and criminal cases. The introduction of Native Authority in these areas was not too antithetical to the existing social and political structures. However, taxation was difficult to introduce, because although there existed tributary relationship between the kings and their subjects they were not accustomed to the organization of the treasury in a systematic manner. Therefore, the introduction of taxation led to riotous protests, particularly in Abeokuta and Ogbomosho. Apart from this, the indirect rule failed here 
due mainly to the rising educated class in the society craving for radical changes in the local government system.

In the Eastern parts of Nigeria, the indirect rule system failed woefully owing to a number of reasons. The Igbo society is basically an acephalous society where there did not exist a centralized authority. The traditional socio-political structure conflicted with the new system of the appointment of warrant chiefs who lacked legitimacy. There was no indigenous system of taxation to provide financial support to the Native Authorities. The introduction of direct taxation by the colonial administration in the area between 1927-1929 provoked serious riots in several parts of Eastern Nigeria, popularly called Aba women riot of 1929. The substitution of British District or Divisional officers in place of warrant chiefs to preside over Native courts after 1922 added to the outrage felt by the citizens of the region which they regarded as imposition; and hence the severity of the opposition.

By 1950 there were 246 Native Authorities in the country. The North had 144, West 55 and East 47. The system of indirect rule continued up till the later part of the 1940s with minor adjustments, especially in the south to make it work. The minor reforms were aimed at absorbing the growing educated and enlightened classes into the system to make it function effectively. According to Daudu. (1980).

By 1921, the basic structure of the N.A. system had been perfected. It was untampared with until the $50 \mathrm{~s}$ when Nigerians began to participate actively in legislative function at the national level. From then onwards, Nigerian leaders in the various legislative houses introduced new laws for governance at the local level.

It is clear from the above that the unified local government system introduced by the colonial administration was not tampered with until the 1950s. However, as from 1951 new changes were introduced by the colonial government.

\section{$1.4 \quad$ The Representative or Democratic System of Local Government-(951-1966)}

This period witnessed the breaking away from the colonial past. The unified local government structure introduced in 1914 gave way to the introduction of different systems of local government in the then three regions-North, East and West. The end of the Second World War in 1945 had a tremendous effect on the policies of the colonial masters and this more than any factor led to the Macpherson constitution of 1951. Also, the end of the war saw great social and political activities in Southern Nigeria, particularly in Eastern Nigeria because of the great influence of Sir Nnamdi Azikiwe. Together with Chief Obafemi Awolowo in Western Nigeria they intensified their demands for greater participation in the local government affairs in their country. This was why Gboyega (1978:34) remarked that, "Dr. Azikiwe's attitude towards Native Authorities and the manner of their composition was not markedly different from Chief Awolowo's".

In 1947, during a Legislative Council debate at Ibadan on the democratization of local governments and the enforcement of the law regarding intrigue against the position of traditional rulers, Azikiwe (1961:76) observed that, "we should be careful not to stultify traditional institution or vest traditional rulers with absolutist power which were undreamt of, before the coming of the British". These nationalist leaders and the educated elites in Southern Nigeria were united on the need to democratize the local government system. In spite of these nationalists' agitations for reforms in the local government system in Nigeria, the ultimate efforts towards the modification of the colonial system of local government was started by the British colonialists themselves on the eve of self-government. In 1947, there was a "popular dispatch" from the Colonial Secretary, Authur Greech Jones, to all Governors of British Colonies in Africa which emphasized the development of an efficient and democratic system of local government. It was this incident that gave the Nigerian nationalists a useful weapon to intensify their demands for a more democratic system of local government, which eventually led to the Ibadan Conference and the 1951 Macpherson Constitution.

The series of political changes and demands for constitutional reforms in the late 1940s which led to 1951 Macpherson Constitution placed the burden of Local Government Policies on the three regional governments-North, East and West. More significant however, was the transfer of the responsibilities for making these policies from the colonial administrators to the Nigerian political leaders. The 1951 Constitution therefore, did not only put an end to the long standing efforts, started in 1914 to impose a unified local government policy on Nigeria but also ended the dominating influence of colonial administrators on such policies.

The most paramount issue concerning local government in the succeeding years was that of "democratization" at the local level. The degree of democratization accepted by each regional government dictated in large measure the extent to which local government institutions were re-organized.

In the efforts to break with the colonial past with its Native Authority system, the political leaders in the south strengthened local institutions. Some of the measures taken to strengthen local institutions included increased powers in the field of education, health, public works, powers to employ qualified administrative and 
professional staff instead of depending on officials seconded from the Regional Government, popularly elected councils instead of councils appointed by Chiefs and Officials and the weakening of the powers of the Divisional Officer (D.Os) and Traditional rulers. (Gboyega, 1978:37-40).

In the Eastern Region, several systems of local government administration were tried with varying degrees of success. In 1950 even before the Macpherson Constitution came into being, the Eastern Regional Government passed the Eastern Regional Local Government Ordinance of 1950. This ordinance introduced a three-tier form of popularly elected councils consisting of County Council, District Council and Local Councils. The interest of Government was to make the second tier (District Council) the most important tier of Local Government, because the districts were not too far away from the grassroots but they were large enough to provide reasonable services.

In the Western Region, the Local Government Law of 1952 introduced representative system of local government for the whole region. To a great extent this law borrowed ideas not only from the North and Eastern regions but substantially the major theme of the law was the transplantation of the British system of Local Government-Divisional Council, District Council and Local Council. Here, the major focus was on the District Council. In the new system the powers of the D.O's who were then the be-all-and-end-all in the colonial era was considerably weakened and the elected members of the Council were given considerable powers to develop their communities. The law was also designed to weaken the role of the traditional rulers who hitherto were very powerful and often despotic.

It is clear from the above, that the Eastern and Western regions established their new local government systems on the pattern of the English model which had County, District and Local Councils. The experiments of the two regions proved an abysmal failure which may well serve as a lesson and guide to the adoption of a foreign system without due regard to the socio-economic as well as the cultural and political setting of the receiving society.

Unlike in the South where changes in the old system were pervasive, the keynote to policy in the North was gradualism. It is however, incorrect to say as some have suggested, that 'agitation' for reform in the local government system in Northern Region was aimed at little more than the elimination of corruption. There were calls for modern, secular and democratic system of local government. For instance, the reforms of the Native Authority system were inspired by the forthright denunciation of the prevailing Native Authority system under indirect rule by the Late Prime Minister, Sir Abubakar Tafawa Balewa in his widely publicized speech of August 1950 in the Northern House of Assembly sitting at Kaduna which led to the setting up of the Commission of Enquiry headed by Messrs K.P. Maddocks and D.A. Pott in 1950.

Similarly, Alhaji Ahmadu Bello, the Sardauna of Sokoto who was appointed Minister of Local Government, and a member of the ruling dynasty in Sokoto played significant roles in the minor reforms and the stability of the prevailing local government system in Northern Region (Gboyega, 1987:63-64) However, it must be generally admitted that the North, unlike the Southern parts of Nigeria refused to be rushed, not only on the issue of democratization, but also on making any drastic reform in the system of local government inherited from the colonial administrators. The Local Government system practiced in the North was so perfected that it has been said by Campbell (1963) that:

...if the wheels of the Native Authorities of the North ceased to turn the Regional Government would find itself in a very difficult position. This may or may not be true but certainly the tradition and authority of the Native Authorities form an integral part in the Government of the North, and one which the common people would not be willing to change.

In the North, the Native Authority Law was passed in 1954 following an investigation into the Local Government structure in the area. Following from the recommendations made aristocratic tendencies and practices were removed and a more democratic system was established. As earlier indicated, the North instead of introducing a new brand system, adopted piece-meal improvements to the Native Authority Law of 1954 by various amendments in 1956, 1957, 1958, 1960 and 1961. According to Daudu (1980), the major ingredients of the 1954 Native Authority Law are five (5) different types of Native Authorities Viz:

1. A Chief or other person in Council;

2. A Chief or other person and Council;

3. A Council;

4. A group of persons;

5. A sole Chief or other person.

At this time, the Native Authorities enjoyed considerable powers which were derived from powers conferred on it by the $1954 \mathrm{Law}$, the powers which were given by other laws or ordinances and the powers conferred by Native Law and Custom. (Gboyega, 1978:73-77). 


\subsubsection{Problems of the Representative System of Local Government}

Scholars and practitioners of local government were also unanimous that the local government experiments in Southern Nigeria in the period of 1950 to 1966 were dismal failures. The situation in Northern Nigeria was however far better than in the South owing principally to factors which are very well known i.e. the stability of the socio-cultural and centralized political situation in the region even before the advent of colonialism and the introduction of indirect rule system.

The following reasons offered by Gboyega (1987:55-56) can be adduced for the failure of the representative or democratic system of local government introduced in Nigeria from the 1950s which lasted till 1966.

1. There was great emphasis on the political, to the neglect of the administrative, which are conditions for an effective local government system. The reform was seen as basically a means of ensuring political participation. Little regard was paid to the financial conditions for a viable system of local government. The financial base of the reformed local government councils were too weak to support the superstructure of the new responsibilities (Lloyd and Wraith, 1953:79, 1955:103). Moreover, the excessive fragmentation which efforts were made to reverse later added to the financial inadequacy of the local councils.

2. There was exceedingly high incidence of corruption among councilors and council employees alike. The widespread corruption, particularly in the south sapped not only the finances of local authorities but also the confidence which people had in the councils.

3. There were far too many authorities. The proliferation of authorities was a consequence of the participatory view which the Regional Governments took of local government. The large number of authorities meant a fragmentation of resources of a locality which were meager to begin with. Therefore, the revenue bases were weakened further by fragmentation. As a result of the above, the councils could not adequately provide the people with social services which also led to non payment of taxes and rates willingly.

4. There were negative political influences of political parties in the local government process. The political parties were blamed for extreme politicking at the local level and for deterring high caliber citizens from taking interest in the affairs of the local government councils through the rabble-rousers in their ranks. Inspite of this obvious problem the existence of political parties helped to enlighten, infuse order and coherence and to structure and articulate local aspirations.

5. Local Government Councils lacked enough trained staff. In 1950, only a handful of native authorities had employed executive officers, the pioneer clerks or executive secretaries as they were then called. The Local Government could not compete with the regional governments either because of poor remunerations or lack of employment opportunities.

6. There were intense rivalries within councils and between ties of councils due mainly to the fragmentation of councils to satisfy the urge of participation. There were conflicts over functions and revenue items to be collected by the councils or tiers of councils.

7. The high expectations of the people for greater dividends of the new local government reforms were not met. The functions assigned to the local government councils were far beyond their resources. The structure of public finance did not take adequate cognizance of the burdens entrusted to the local authorities.

The defects of the local government councils operated between 1950 and 1966 in Southern Nigeria were not different from the findings of the Red-cliffe-Maud Commission on Local Government in England at the same period. This conclusion point to the fact that the problems were inherent in the structure or system which was adopted (Report of the Royal Commission, 1969).

In summary, it could be said that the problems or factors which led to the failure of the representative or democratic reforms of the 1950s were that there were rivalries within councils and between tiers of councils. The rivalries were so intense that often agreement on even minor issues was impossible. There was an excessive parochialism and irrational grip of power politics, which made mockery of the policy of local self-government. The type of professional and political leadership which was needed to provide unity, direction and inspiration in local affairs was completely absent. Many of the councilors were inexperienced in public affairs with the result that nothing substantial could be offered by them in terms of effective and progress-oriented services. Many of the councilors had no visible means of livelihood so that their dependence on income from public office went beyond that provided as sitting allowances. This led to wide spread corruption and mismanagement.

The intensity of the problem was such that many began to ask whether the transformation of Native Authorities with limited powers into Native Authorities with considerable powers was not so sudden and drastic. This situation prompted Rt. Honourable Nnamdi Azikiwe, then Minister of Internal Affairs during a parliamentary debate in 1956 to state that: 
The experience of the last five years has shown many cases of immaturity and inexperience and let be admitted with regret of irresponsibility and dishonesty, that this stage of development, a stricter control than was originally thought is required (Zik, 1961:76).

It is clear from the above that the leadership problem was one of the serious problems that militated against the success of the new liberal local government system introduced in the 1950s.

Owing to a number of reasons, such as lack of finance and personnel, attempts to reform the system between 1957 and 1966 were ineffective (Humes 1970:98-101). The military intervention and the subsequent transformation of Nigeria into twelve (12) states' structure gave a fresh opportunity to decision makers in the new states to examine the role of Local Governments within the new political framework.

\subsection{Local Government under the Military (1966-1975)}

As soon as the military assumed power, it declared its intention to carry out far-reaching reforms of the existing system of local government. Immediately in the North, the Native courts were brought under the Regional Judiciary while the N.A. Police and the N.A. prisons were transferred to the Nigerian police and Nigerian Prisons respectively. Two years later, precisely in 1968, the promised reforms of the Local Government systems were launched in virtually all the 12 states in the country and by 1970 the proposals of the Military Government were implemented. According to Aliyu (1980:29), the old Native Authority

System was characterized by the following demerits:

1. Their procedures were often irreconcilable with democratic norms;

2. They were frequently hostile to progressive measures and essential reforms

3. Several N.As had shown total lack of responsibility in the management of public funds and

4. With few exceptions they had failed to attract the qualified staff required for efficient operations and many were financially dependent on government by shortage of funds and staff.

It could therefore, be said that these were the factors, which guided the military in carrying out the reforms of the local government systems which they inherited.

In carrying out the reforms the various state governments had as their objectives the enhancement of popular participation in local government affairs and distribution amenities to the rural areas. In their bid to achieve these stated objectives the State Governments replaced the existing Native Administration (N.A's) with Local Government Authorities. Similarly, Local Government Authorities were re-organized by establishing in their places Administrative and Development Areas.

Having examined the background to the reform of the local government system by the military as well as the stated objectives of the reforms, we shall now proceed to examine how the reforms were carried out in a number of selected states.

In the Eastern states, one might be tempted to thinks that as a result of the chaos that followed the civil war, that direct administration would have taken the place of local government administration. However, this did not happen. Although, a 'real' local government administration did not exist but only a form of 'localized' administration which was an attempt to rehabilitate the region after the war.

In the South Eastern State the Military Government of the state resolved on a wholly new departure which purported to abolish local government altogether. The reasons for this new departure was contained in a "Policy Statement" (1968) which bordered on great bitterness and disillusion. Wraith (1972:184) explains that:

Native Administration under the British Administrators and Local Government under Nigerian politicians were alike dismissed as venal, corrupt and irrelevant to the country's needs... that manpower resources were not sufficient to staff both Central and Local Government; and that Local Government must always be a poor relation with little of its own to contribute; that the division of Regions into states had brought the Central Government sufficiently near to the people to dispense with shared central-local responsibilities.

The South Eastern Government therefore, adopted "Development Administration" in place of the old structures. Under this new arrangement, 140 "Area Development Committees" were formed as well as eleven "Divisional Development Councils". It is often argued that this new arrangement did not differ from the old system except in nomenclature.

In the East Central State, the State Government established a "Divisional Administration" based on a system of local authorities intended primarily to co-ordinate the activities of the state government functionaries in the Division and in the Local Government in such a way to ensure proper decentralization of functions. It was also to ensure active participation of the local people in the general development and management of their own affairs under the supervision and guidance of the local authority. The Local Administrations reverted to the 
'Division' but the 55 Divisions under the provincial days were reduced to 34 with populations of between 100,000 and 300,000. Three of these, Enugu, Aba and Onitsha were urban Divisions.

In the Western State, a 39 all-purpose councils i.e. Council Manager Areas replaced the old local government structures. In the Council-Manager system, elected councils were abolished and administrators or appointed committees ran the affairs of the authority with the help of their staff. This system was intended to bring about greater efficiency in the delivery of services. The Councils were thus, ran like commercial enterprises. In 1969 the administrators or appointed committees were supplemented by "advisory committees" comprising of ten unpaid members with the District Officers as Chairmen.

An examination of the reforms in the North shows that some of the old N.As were divided, some merged while others were restructured in some ways. It is important to know that the six Northern States fall into three pairs of what might be called "Basic Local Government Arrangements".

The first pair is Benue Plateau and Kwara states which although differ in details but which basically continued a relatively familiar form of divisional administration. In Benue Plateau State, there were nine divisions, six of which were co-terminus with the newly established "Local Administrations" and three were sub-divided which gave a total of fourteen "Local Administrations" in all.

In Kwara State, eleven Local Administrations were created, each co-terminus with the eleven Divisions. Sole administrator were in charge of each of the new authorities.

In Kano and North Central States, the new administrative machinery adopted to bring government nearer to the people was known as the "Administrative Area". The Administrative Areas were presided over by administrative officers with a Council, which were at that time nominated while District Heads sit as ex-official members. In this set up the powers of the Emirs tended to diminish and it would appear that the reform intended this to be so.

Finally, in the North Western and North Eastern States, the old N.As simply changed their names to Local Authorities except in North East where some "Federated Native Authorities" were unified into single new Local Authority. The new change that was introduced in both States was that the new Local Authorities were divided into "Development Areas" while in the North West there were twenty three of them. The function of this new body was to stimulate development within the Local Authority areas operating through "Development Boards" whose executive functions were vested in Secretaries appointed from the State public service.

The Emirs and Chiefs remained as Presidents or Chairmen of their Local Authority Councils. Here again, the powers of the Emirs were considerably reduced as they now have only voting rights and not the right to veto council decisions as was the case in the era of "Chief-in-Council".

As before the reformed Local Government Authorities "lacked not only independent revenue capacity, but also the executive and absorptive capacities". In other words, they were financially dependent on higher authorities. Lack of qualified staff both administrative and technical and the fact that the members of the reformed local government administrations continued to be nominated and therefore had no commitment and moral obligation to the people in the rural areas made a mockery of the reforms.

It must be concluded that the reformed local governments however structured and operated were run like decentralized units of state governments between 1968 and 1975. Indeed one can confidently say that no meaningful reform was undertaken by the military. It is therefore obvious that when in 1976 the Military Government of General Murtala Mohammed/Obasanjo carried out its reform, it had its conviction about the inadequacies of the prevailing local government system and the necessity for a drastic change.

\subsection{The 1976 Local Government Reform}

In 1976, the Federal Government introduced the local government reforms, which marked a turning point in local government administration in the country. The reforms were the Federal Government's response to the recommendations of the Udoji Public Service Review Commission. The aim of the reforms was to make the local governments more effective in their primary role of bringing development to the grassroots. The reform established a multi-purpose single tier system throughout the country, with the same structure and functions. Local Governments were recognized as a third tier of government within the federal structure. The 1979 Constitution recognized local government as such thus reinforcing the main features of the reform.

The reform of the local government system was not only important and desirable, but it was a crucial element in the political programme of the Federal Government under General Olusegun Obasanjo as Head of State in 1976. The reforms were initiated because of the inherent defects of the previous local government system practiced under the military between 1968-1975. In the Forward to the Guidelines for Local Government Reforms (1976) the Chief of staff, Supreme Headquarters, Brigadier Shehu Musa Yar'Adua elaborated on these defects when he said:

Local Governments have over the years suffered from the continuous whittling down of their powers. The State Governments have continued to encroach upon what would normally have been the excusive preserves of 
Local Government. Lack of adequate funds and appropriate institutions had continued to make Local Governments ineffective and ineffectual. Moreso, the staffing arrangements to ensure a virile local government system had been inadequate. Excessive politicking had made even modest progress impossible. Consequently, there has been a divorce between the people and government institutions at their most basic levels.

The reform of the local government was intended to stimulate democratic self government and to encourage initiative and leadership potential, as well as the mobilization of the human and material resources for local development. Specifically, the aims and functions of the reformed local government which can be found in the Guidelines for Local Government Reforms (1976) are specified here under:

\subsubsection{Aims and Functions of the Local Government Reform}

The principal aims of the local government reform are:

a. To make appropriate services and development activities responsive to local wishes and initiatives by devolving or delegating them to local representative bodies

b. To facilitate the exercise of democratic self-government close to the local levels of our society and to encourage initiative and leadership potential.

c. To mobilize human and material resources through the involvement of members of the public in their local development.

d. To provide a two-way channel of communication between local communities and government (both State and Federal).

In general, the functions which Local Government bodies should perform should be those:

a. Which require detailed local knowledge for efficient performance;

b. In which success depends on community responsiveness and participation;

c. Which are of a personal nature requiring provision close to where the individuals affected live, and in which significant use of discretion for understanding of individuals is needed.

Provided the services can be effectively rendered on the scale of a Local Government area or at most a joint board of neighbouring Local Government bodies.

Although, no rigid rules can be laid down as to what functions should be devolved to Local Governments, the subjects listed in the exclusive list should exclusively be entrusted to Local Governments. These functions should be the exclusive responsibility of local government save in exceptional circumstances. In other words where some local governments are unable to undertake such responsibilities, the state governments should under such circumstances perform these functions. The list is not exhaustive, additional functions appropriate to at least some local governments could be identified now or in the future. It is essential that local governments should have adequate and assured funds for the discharge of duties entrusted to them.

Items which are the responsibility of local governments save under exceptional or temporary circumstances are:

- $\quad$ Markets and Motor parks;

- $\quad$ Sanitary inspection, refuse and night soil disposal;

- Control of Vermin;

- $\quad$ Slaughter houses, slaughter slabs;

- Public conveniences;

- Burial grounds;

- $\quad$ Registration of births, deaths and marriages;

- Provision of community and local recreation centers

- $\quad$ Parks, gardens and public open spaces;

- $\quad$ Grazing grounds, fuel plantations;

- Licensing supervision and regulation of bake houses, and laundries;

- Licensing and regulation of bicycles, hand carts and other types of vehicles except those mechanically propelled, and canoes;

- Control or keeping animals;

- Control of hoardings, advertisements, use of loud speakers in or near public places, drumming.

- Naming of roads and streets and numbering of plots/buildings;

- Control and collection of revenue from forestry outside the forest Estate if gazette Forest Reserves ;

- Collection of vehicles parking charges.

- Collection of property and other rates, community tax and other designated revenue sources. 
Items which should be regarded as local responsibilities although state governments and other organizations may also perform part or whole of these functions if local governments are not equipped to perform initially, which are contained in the concurrent legislative list are as follows:

Health centres, maternity centres, dispensaries and health clinics, Ambulance services, leprosy clinic and preventive health services-Abattoirs, meat inspection;

- Nursery and primary and adult education.

- Information and public enlightenment;

- Provision of scholarships and bursaries.

- Provision of public libraries and reading rooms;

- Agricultural extensions, animal health extension services and veterinary clinics;

- Rural and Semi-Urban water supply.

- Fire services

- Provision of roads and streets (other than trunk roads) their lighting drainage;

- Control of beggars, of prostitution and repatriation of destitute;

- Provision of homes for destitute, the infirm and orphans;

- Provision of public utilities except where restricted by other legislation

Specifically including provision of road and inland water transport; public housing programmes, Operation of commercial undertaking, control regulation and control of buildings; Town and Country Planning. Piped sewerage systems (Guidelines for Local Reform 1976:1-3).

\subsubsection{Features of the 1976 Local Government Reform}

The main features of the 1976 Local Government reform are as follows:

1. Uniform and standardized system of local government throughout the country. The population of a local government should range from 150,000 to 800,000 .

2. The local government became a third tier institution within the federal structure.

3. For the first time in the political history of local government in Nigeria, Local Government was entrenched in the 1979 constitution which was intended to reinforce the provisions of the 1976 local government reform.

4. A relatively high level of autonomy was granted to the local governments.

5. The local governments were given specific functions to perform and enshrined in the $4^{\text {th }}$ schedule of the 1979 constitution.

6. The local governments were democratized, through popular or indirect elections.

7. Local governments were constitutionally entitled to revenue from the Federation Account and from the State Governments.

8. Traditional Councils or Emirate Councils were to be constituted in line with the guidelines to the reform. A far-reaching departure was the insulation of traditional rulers from participation in local government affairs, save in an advisory capacity to the elected of appointed chairmen of the local governments.

From all indications, this reform is very important and distinct from other reforms. This was why Adamolekun (1979:3) has observed that, "what distinguishes the 1976 Local Government Reform from all previous reform exercises in the country is the formal and unequivocal recognition of local government as constituting a distinct level of government with definite boundaries, clearly stated functions, and provision for ensuring adequate human and financial resources".

\subsubsection{Defects of the 1976 Local Government Reform}

The 1976 Local Government Reform which was adopted by the 1979 Constitution had some anomalies which made the reform not to survive for a long time before amendments were made. Some of these defects are as follows:

1. Uniformity and standardization: The population of the local government should range between 150,000 to 8,000 . This did not make for efficiency and effectiveness of the councils.

2. The objective of bringing government closer to the people was largely defeated by the large size of some LGAs e.g Epe Local Government Area covered about half of the size of the whole of Lagos State, yet it was then one local government.

3. Because the Federal Government set the limit to the number of council wards and councilors that could be elected within an LGA, some of the wards in the LGAs were excessively large and therefore out of touch with the electorates.

4. Some of the States Local Government Edicts grouped together communities with little or nothing in common both in out-look, culture and other requirements with the result that such areas witnessed incessant disagreements and instability. 
5. Grouping of unidentical villages or communities with a view to getting the required minimum population of 150,000 per LGA. Similarly, some towns and villages which were geographically contiguous and therefore, similar in their outlook and ways of life were split between two LGAs because of their large size and population stipulation of 800,000 .

\subsection{Local Government Reform under the Babangida Era and the Introduction of Presidential} System at the Local Government Level

The inadequacies mentioned earlier on and the arbitrary powers of the state governments over the local government councils made Nigerians to embark upon a search for a better system of local government that would stand the test of time. Based on the Political Bureau and Dasuki Reports of 1987, the Federal Government created sub-ordinate units out of the 301 multi-purpose units called local governments. Each local government council was structured into a pyramidal format with the village constituting the primary unit, the Development Area Office constituting the intermediate unit while the local government council constituted the apex unit. The purpose of this was to achieve the decentralization of services provided by the local government. The villages were to become the target of state and local government programmes and activities. This reform would enable the people themselves to be involved in the supervision, control and guiding local government and other government functionaries deployed to the field. It also envisaged that the people would be more directly involved in the provision of services for their common good. The sum total was that the people would be more meaningfully mobilized for production and community development.

Under this reform exercise, state military governors appointed Caretaker Committees consisting of chairman, vice-chairman, supervisors and a secretary to the local government council. Later in 1987 elections were conducted on non-party bases to run the affairs of the local government councils. This was a prelude to the return of democratic rule to Nigeria. Most of the recommendations of the Dasuki report were implemented by the Babangida regime in its local government reform exercise.

General Babangida set up the Constituent Assembly which came out with far-reaching resolutions which were later entrenched in the 1989 Constitution. The Dasuki Report and the provisions of the 1989 Constitution of Nigeria formed the basis of the local government reform carried out by General Babangida from 1985 and 1993

\subsubsection{The Babangida Reforms from 1985-1993}

The local government in Nigeria witnessed what can be classified as the 'golden era' during the Babangida administration (1985-1993). He introduced measures to enhance the economic viability of the local governments and also ensured more constitutional autonomy for them. Highlights of the local reforms under Babangida include:

a. The direct remittance of local government funds from the Federation Accounts as well as at source deductions of states $10 \%$ internal revenue direct to the local government councils.

b. Increase in the local government share of the Federal Account from 10-15 percent in 1991 and from $15-20 \%$ in 1992.

c. The 1989 Constitution made local governments truly autonomous; hence the Ministries for Local Government throughout the country were abolished on $1^{\text {st }}$ October 1991.

d. Presidential system was introduced at the local government level in 1991. The chairmen and his appointed supervisors formed the executive arm while the elected councilors constituted the legislative arm. This brought about incessant conflicts between the two arms of government and general instability in the local government.

The 1989 Constitution gave the local government councils the status of a third tier system with considerable autonomy. The intension of the framers of this constitution was to erode all past anomalies associated with the subordinate existence of local government councils to the State Government. On $1^{\text {st }}$ October 1991, General Ibrahim Babangida in his budget speech announced the abolition of the Ministries of Local Government throughout the country because of the suffocating control, which the states exercised over Local Governments. The 1989 Constitution recognized 449 Local Governments with the provision for creating more and adjusting the boundaries of the existing ones. Section 7(1) of 1989 Constitution provided for democratically elected Local Government Council, but at the same time, the States were charged with the responsibility for bringing them into being, thus, subordinating the Local Governments to the State Governments.

In April 1991, the Vice-President Agustus Aikhomu, in a nation-wide broadcast announced a two-tier system of local Government i.e. the executive and legislative arms and issued implementation (presidential) guidelines to effectuate the provisions of Degree, No. 10 of 1991. These guidelines were:

i. The executive arm of the Local Government consists of the Chairmen, Vice-Chairmen, Supervisors and the Secretary to the Local Government 
ii. The Councils became the legislative arm with the elected councilors performing legislature functions. The legislators have to elect from among themselves a leader and a deputy leader;

iii. There was head of Personnel Management Department who was designated as a Council Clerk, who keeps proper records of council proceedings.

The 1989 Constitution made provision for the functions of the Local Government Councils headed by the Executive Chairmen, which include exclusive and concurrent functions which were to be performed by both the states and local governments.

The functions of the legislative arm were spelt out as shown below:

i. $\quad$ Law making, debating and passing Local Government legislation;

ii. Debating, approving and possibly amending Local Government annual Budget, subject to the Chairman's veto which could be overridden by two-third majority of council members.

iii. Vetting and monitoring the implementation of projects and programmes in the Local Government annual budgets;

iv. Examining and debating monthly statements of income and expenditure of the local government;

v. Impeaching the Local Government Chairman who has committed an impeachable offence in accordance with the 1989 Constitution.

vi. Advising, consulting and liaising with the local government Chairman;

vii. Performing such other functions as may be assigned to it from time to time by the State House of Assembly.

By this act the presidential system was effectively extended to the local government level in Nigeria by the Babangida regime with several consequences. The provisions earlier listed had far reaching consequences for the running of the affairs of the Nigerian Local Government System. The reform introduced checks and balances into the administration of the local government. However, the council chairmen were so powerful that the elected councilors could not act as effective checks on them. This resulted in all kinds of crimes committed against the local governments. Be that as it may, there is no doubt that the Babangida local government reform was initially successful. It was in the later part of his administration that the situation painted above manifested themselves. To worsen the already ugly trend, the 1988 Civil Service Reform in Nigeria and its application to the local government has done a lot of damage to this tier of government. The combined effects of all the above is the entrenchment of indiscipline, corruption, gross mismanagement, phenomenon of "sharing" and the consequent neglect of rural development in Nigeria.

\subsubsection{Presidential System at the Local Government Level under the 1999 Constitution}

The operations of the Local Government Councils in the present dispensation are guided by the 1999 Constitution of the Federal Republic of Nigeria. It recognizes 774 LGAs as defined by First Schedule Part 1. Section 7(1) of the constitution provides that:

The system of Local Government by democratically elected Local Government Councils is under this constitution guaranteed; and accordingly, the Government of every state shall, subject to section 8 of this constitution, ensure their existence under a law which provides for the establishment, structure, composition, fiancé and functions of such councils.

The implication of this provision is that the local government councils are to be democratically elected but the State Houses of Assembly are invested with the 'power' of making laws for the detailed operations of the councils i.e. functions, structure, composition, finance etc, as deemed appropriate for their states. This implies that the unified system of local government in practice since 1976 has ceased to be. Each state is therefore; free to enact their own laws for the administration of the respective local government in their states. Consequent upon this, the various State Houses of Assembly in the country introduced the presidential system at the local government level through their enabling laws. The same problems associated with the Babangida reforms persisted and have even worsened.

In June 2002, when the tenure of the councils elected in 1999 nationwide expired, the various State Governments did not conduct elections into these councils for over two years. Rather, as in 1979-1983 during Shehu Shagari era, the states resorted to the appointment of transition committees or caretaker committees or by whatever name called which was clearly at variance with the constitution and norms of democracy. Thus, the people at the grassroots were once again denied participation in choosing their leaders and the governance of their own localities. The local government chairmen under this dispensation were very powerful and adjudged by many to be very corrupt. One important trend to observe is that from Babangida era in 1990-1993 and the subsequent regimes to date, the rate and depth of corruption, mismanagement and lack of grassroots development has been on the increase, even in spite of state control of the local governments.

In furtherance of the 1999 Constitution provision on local government, the Benue State House of Assembly for instance, enacted the Benue State Local Government Council Law No. 25 (Establishment Law, 
2000) which provides for the Executive and Legislative arms of the Local Government. The executive arm consists of the chairman, Vice-chairman, Supervisors and Secretary to the Local Government who is head of service. The legislative arm consists of the leader, deputy-leader and Councilors. There is also a Clerk of the Legislative Council appointed by the Local Government Services Commission.

The main functions of the Local Government Councils i.e. executive arm include (See Part VII. Sections 45 and 46 of Benue State Local Government Law 2000).

- The formulation of economic plans and development schemes for the local government areas.

- Collection of rates and insurance of radio and television licenses.

- Establishment and maintenance of cemeteries, burial grounds and homes for the destitute or infirm;

- Licensing of bicycles, trucks (other than mechanically propelled trucks) canoes, wheel barrows and carts.

- Establishment, maintenance and regulation of slaughter houses, slaughter slabs, markets, motor parks, and public conveniences;

- Construction and maintenance of roads, street lights, drains, parks, gardens chief's palace, open spaces or such public facilities as may be prescribed from time to time by the House of Assembly of the state;

- Naming of roads and streets and numbering of houses.

- Provision and maintenance of public conveniences, sewage and refuse disposal.

- Assessment of privately owned house or tenement for the purpose of levying such rates as may be prescribed by the House of Assembly of the state;

- Registration of all births, deaths and marriages; control and regulation of

i. Out-door advertising and hoarding

ii. Movement and keeping of pets of all description.

Functions of a local government Council shall include participation of such council in the Government of a State as respects the following matters.

a. The provision and maintenance of primary, adult and vocational education;

b. The development of agriculture and natural resources, other than the exploitation of minerals.

c. The provision and maintenance of health services; and

d. Such other functions as may be conferred on a Local Government by the House of Assembly of the state.

The main functions of the Legislative arm are contained in Part VII, Section 47 (a-d) of the Benue State Local Government (Establishment) Law 2000. These are:

a. Debating, approving or amending the annual budget of the Local government subject to the Chairman's veto, which may be set aside by two-third majority of members of the Local Government Legislative Council;

b. Vetting and monitoring the implementation of projects and programmes in the annual budget of the Local Government from time to time;

c. Examining and debating the monthly statement of income and expenditure rendered to it by the chairman of the Local government;

d. Impeachment of Local Government Chairman who commits impeachment offence in accordance with the constitution.

e. Advising, consulting and liaising with the chairman of the Local Government, and performing such other function as may be assigned to it from time to time by any law of the state.

The introduction of the 1991 Presidential System as well as the 1999 constitutional provision on local government was to achieve the following objectives:

- Strengthen the local government system and enhance its status and autonomy by giving it a parity of treatment with higher tiers of government, thus enabling it to fully fulfill its assigned roles as the third tier of government in the Federation.

- Streamline the practice at the local government level with what obtains at higher tiers of government, thus facilitating the internationalization of the principle and practice of presidential system at the local government level. This is bound to serve as significant training ground for leadership at the higher tiers of government.

- Strengthen the system of checks and balances by the establishment of the Office of the Auditor General of Local Governments, the process of Audit alarm and the principle of recall. There was also the need to check the excesses and abuses pertaining to the management and application of public funds and resources (Oyelakin, 1992). 


\subsubsection{Statutory Checks on the Powers of the Chairmen and their Executive under the 1989 and 1999 Constitutions}

In view of the enormous powers and functions of the chairmen and their executives there was likelihood of corruption of power and hence the need to make laws that will control their activities. The following laws were made in this respect:

i. The Chairmen and Vice Chairmen of Local Governments can be removed from office by the president under section 34 and 292 of decree No.15 of 1989 and the 1989 Constitution respectively for gross mismanagement.

ii. Further more section 23 and 304 of decree No. 15 of 1989 and the 1989 Constitution respectively provided for the recall of the Chairman and other members of the council which operate in the nature of vote of no confidence passed on the effected member by his own people who voted him.

iii. Again, there is Local Government Service Commission established by section 29 and 195 of decree No. 15 of 1989 and 1989 Constitution respectively. The primary function of the Commission includes to serve as a review body for all petitions from the local governments in respect of appointments, promotions, and discipline.

iv. The Chairmen and other members of the council were compelled to observe and conform to the code of conduct under the Code of Conduct Bureau and Tribunal Decree of 1989 and 1989 Constitution respectively.

v. In case of financial control the office of the Auditor General of Local Government was established and was charged with the responsibility of auditing of all accounts of the local governments without direction from any other authority or person.

vi. The legislative arms of the local government can exercise legislative powers by enacting bye-laws on any matter but can only become law when assented to by the chairman and is also not contrary to the provisions of the state law and the constitution of Nigeria.

vii. The general functions of the legislative arm of the local government are a further check on the power of the executive arm of the local government.

viii. Power of House of Assembly to suspend or remove local government chairmen. Under section 6 of the Benue State Local (Establishment) law, 2000, the House of Assembly has powers under section 128 and 129 of the 1999 Constitution to suspend any Chairman or council to enable proper investigation and determination of allegations against such chairmen or council. If such allegations are proved, this could lead to removal of the chairman or dissolution of the council.

ix. The Anti Corruption Law (ICPC) of the Federal Government is a further check on the powers of chairmen, their executives and the legislative arms of the local government.

\subsubsection{Problems arising from the Introduction of the Presidential System at the Local Government} Level

There are a number of problems that have arisen from the introduction and practice of the presidentialism at the local government level. Some of these problems include the following:

i. Problem of inter-governmental relationship: By the introduction of the presidential system at the local government level, one presupposes the existence of local government autonomy. But under the 1989 and 1999 Constitutions, there is no autonomy for local government because there has been many instances of interference by both the state and federal governments. Also there are possibilities of role conflicts over functions as a result of overlapping responsibilities. The local governments are usually the greatest loser in the equation.

ii. Conflict between the legislative and executive arms of the local government because of the separation of powers and functions:

a. The tendency of the legislative arm to misuse the impeachment clause as a result of many grievances, real or imagined;

b. The non participation of elected councilors in the administration of the local government like contract awards, staff recruitment, postings etc are sources of their grievances.

c. The councilors became part-time legislators to "meet at least once in a month" contrary to their expectations. Worst still, there was not much to legislate upon, so they have become redundant most of the time.

d. The Secretaries, Supervisors and other aides appointed by the chairmen took over their places as executors of local government programme with much advantage accruing to them at the detriment of the councilors.

e. Corruption and misapplication of funds as a result of the constant threats of impeachment by the legislators. Very often the chairmen use this opportunity to misappropriate and mismanage local government funds.

f. Constant instability in the local government system as a result of ranglings and squabbles between the legislative and executive arms of the local government over the spoils of office. 


\section{Conclusion}

It can be observed that the Nigerian local government system has witnessed significant reforms in the past nearly sixty years, beginning from 1951.The reforms redefined local governments and changed their orientation from field administrations of the state governments to being semi-autonomous local government structures that were responsible to their electorates. One of the important aspects of the reforms was the policy that local governments are now entitled to a proportion of the funds from the federal account. Increased allocation of resources into local government system has ensured that local governments have access to substantial revenues to enable them to execute the range of responsibilities allocated to them by the reforms and subsequently by the constitution. Another important innovation of the reform was/is the policy decision to provide training at all levels to all categories of local government officials in three Nigerian Universities; Obafemi Awolowo University, Ile-Ife, Ahmadu Bello University, Zaria and University of Nigeria, Nsukka.

The progress made in the local government reforms in the 1970s were virtually eclipsed in the early 1980s when the authority vested by the 1979 Constitution in the states to create local government led to a proliferation of local governments which over-stretched the limited capacity of governance at the local government level. This situation was halted after the fall of the 1979-1983 civilian administration of Alhaji Shehu Shagari in the 1983 coup d'tat led by the Buhari/Idiagbon.

The creation of states in Nigeria has always led to the creation of more local governments by the military. The number of local governments rose from 229 in 1970 to 301 in 1979 and to a peak of 781 when state governments were given authority by the constitution to create local governments. After the overthrow of the civilian administration in 1983, the number was again reduced to 301 and later raised to 449 in 1987, 589 in 1991 and 774 since 1996. The urge to create more Local Government Areas has been rejected by the federal government. This issue was a subject of litigation between the states and the federal government, which the latter won. This situation led to the withholding of the funds meant for the local government councils in Lagos State during President Obasanjo's era. However, this action was voided by the Supreme Court. Therefore, all the local government areas created by the state governments then have been reverted to development areas

During the Babangida era, from 1988, the federal government strengthened local government institutions by abolishing the Ministries of local governments, paying federal allocations direct to the local governments, granting local governments authority to prepare and approve their own budgets and taxes independently, transferring primary education and primary healthcare and all related issues and increasing the local government share of federation account.

From 1999 when the present administration came into being, the fates of local governments have declined. The 1999 Constitution has placed local government directly under the state's control, Ministries of local government have been reestablished in many states, and no more direct funding of local governments and the practice of presidentialism at the local government level is now in place in many states of the federation. Today, however, local governments remain the key institution in local governance. It is the basic unit of the country's political system, the primary level of grassroots political mobilization, and a major reference point in the distribution by government of certain economic and social goods and services (Otobo E. "Nigeria", in Adamolekun L. (ed) 2002).

\section{References}

[1]. United Nations (1959). Public Administration: Aspect of Community Development, New York.

[2]. Oyediran O. (1988). Essays on Local Government Administration in Nigeria: Lagos, Project Publishers.

[3]. Federal Republic of Nigeria (1976). Guidelines for Local Government Reform, Government Printer, Kaduna.

[4]. Akpan, P.C. (1984). Modern Local Government Administration in Nigeria: Kaduna, Baraka Press.

[5]. Adewumi, J.B. (1988). "The Role of Political Executive under the 1988 Civil Service Reforms", in Ngum (ed). Evolution of Nigerian Civil Service: The 1988 Reform, Zaria Gaskya Corporative Ltd.

[6]. Akaakuma, A. (2008). Ethics and Accountability in Administration, MPA/PAD 706 Lecture Notes, Benue State University, Makurdi.

[7]. Aliyu, A.Y. (1980). "Local Government Reform in Nigeria: An overview", Kumo S. and Aliyu, A.Y. (ed) Local Government Reform in Nigeria, Department of Research and Consultancy, Institute of Administration, ABU Zaria.

[8]. Writh R.E. (1964). Local Government in West Africa, London (George Allen and Unwin)

[9]. Federal Republic of Nigeria (1999). The 1999 Constitution, Abuja, Government Printer.

[10]. Adamolekun, L. (1979). "The Idea of a Local Government as a Third Tier of Government", in Adamoleun, L. and Rowland, L. (ed) The New Local Government System in Nigeria, Ibadan Heinemann Educational Books (Nig.) Limited.

[11]. Federal Republic of Nigeria (1991). Decree No. 10, Abuja, Government Printer.

[12]. Federal Republic of Nigeria (1989). The 1989 Constitution, Lagos, Government Printer.

[13]. Benue State of Nigeria (2000). Local Government Establishment Law, 2000; Makurdi, Government Printer.

[14]. Lugard, F. (1922). "The Dual Mandate in British Tropical Africa, (ed) Orewa, G.O. and Adewumi, J.B. (1983). Local Government in Nigeria: The Changing Scene, Benin City, Ethiope Publishing Corporation. 